\title{
ANALISIS SIKAP KONSUMEN DAN KEPUASAN KONSUMEN TERHADAP MINUMAN YAKULT (STUDI KASUS PADA MASYARAKAT KOTA BIMA)
}

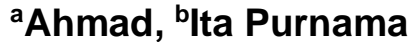 \\ ${ }^{a b}$ Sekolah Tinggi Ilmu Ekonomi Bima \\ abahmadpolan5@gmail.com
}

\begin{abstract}
ABSTRAK
Penelitian ini bertujuan untuk mengetahui sikap dan kepuasan konsumen terhadap minuman probiotik yakult, dimana populasi yang di gunakan dalam kegiatan ini adalah masyarakat kota bima yang pernah minum minuman probiotik yakult yang jumlahnya tidak di ketahui (unknown population) dengan jumlah sampel 96 orang .Tehnik pengumpulan data yang di gunakan yaitu Studi pustaka, Obsevasi dan juga Angket. Dari hasil pengujian validitas terhadap setiap pernyataan instrumen penelitian pada variabel sikap konsumen dan kepuasan konsumen dapat dikatakan semua item pernyataan yang diajukan dalam penelitian ini adalah valid karena berada diatas standar validitas yaitu $>0,300$, berdasarkan ouput spss uji reliabilitas variabel sikap konsumen dan kepusan konsumen di katakan reliabel karna lebih dari 0,6. Uji one sample rumus t-test satu sampel. Nilai $t_{\text {tabel }}$ dapat dihitung dengan menggunakan $d k=n-1 \quad(96-1=95)$ dengan derajat kesalahan $5 \%,(0,05)$ maka diperoleh nilai $t_{\text {tabel }}=1,665$, karena nilai $t_{\text {hitung }}$ lebih besar dari $t_{\text {tabel }}(65,219>1,665)$ maka jatuh pada daerah penerimaan Ha artinya Ha terima dan Ho ditolak.maka sikapkonsumen dan kepuasan konsumen di atas kriteria yang sudah di tentukan yaitu $70 \%$.
\end{abstract}

Kata Kunci : Sikap Konsumen, Kepuasan Konsumen

\begin{abstract}
ABSRACT
This study aims to determine consumer attitudes and satisfaction with yakult probiotic drinks, where the population used in this activity is the people of Bima city who have ever drank yakult probiotic drinks whose number is unknown (unknown population) with a sample of 96 people. Data collection techniques which is used is literature study, observation and also a questionnaire. From the results of testing the validity of each research instrument statement on the variables of consumer attitudes and consumer satisfaction, it can be said that all the statement items proposed in this study are valid because they are above the validity standard, which is $>0.300$, based on the SPSS output of the reliability test of the variables of consumer attitudes and consumer satisfaction in the statement. reliability because it is more than 0.6. test one sample formula t-test one sample. The value of ttable can be calculated using $d k=n-1 \quad(96-1=95)$ with a degree of error of $5 \%$, (0.05) then the value of ttable $=1.665$, because the value of tcount is greater than ttable (65.219> 1.665) then it falls in the area of acceptance Ha means that Ha accepts and Ho is rejected, so consumer attitudes and customer satisfaction are above the predetermined criteria, namely $70 \%$.
\end{abstract}

Keyword : Consumen Attitude, Consumen Satisfaction

\section{PENDAHULAN}

Perkembangan hidup masyarakat kota membawa konsekuensi pada gaya hidup yang di jalanin mereka. Gaya hidup masyarakat kota dapat di lihat dari aktifitas keseharian, interest, kebutuhan hidup, mode yang di pakai dan lain sebagainya, yang kesemuanya 
terlihat berubah dari kebiasaan sebelumnya. kebutuhan manusia menurut tingkat kepentingannya (intesitasnya) dibagi tiga bagian yaitu kebutuhan primer,kebutuhan sekunder, dan kebutuhan tersier. Kebutuhan primer adalah kebutuhan yang mutlak yang harus di penuhi dan seandainya kebutuhan tidak bisa di penuhi maka kelangsungan hidup manusia dapat terganggu.

Kebutuhan primer contohnya makanan, minuman, pakaian, dan kesehatan. Manusia perlu minum karna merupakan hal yang paling penting sebagai salah satu cara mempertahankan hidup sekaligus menghilangkan haus. Sering kali manusia menyepelekan kesehatan dalam hal ini kesehatan usus, Usus adalah bagian dari sistim dari pencernaan yang bermula dari lambung hingga ke anus, ketika usus bermasalah akan berdampak pada keberlangsungan kehidupan manusia. Maka mengkonsumsi minuman probiotik adalah salah satu cara untuk meminimalisir terjadinya penyakit usus. Mimuman probiotik adalah minuman yang mengandung sejumlah bakteri biotik dan juga minuman probiotik biasanya memiliki rasa yang enak, segar, aman dan bisa di konsumsi oleh siapapun. Dari sekian banyak jenis minuman probiotik yang ada di pasaran salah satu minuman perbiotik yang paling di gemeri adalah minuman probiotik yakult.

PT.Yakult merupakan perusahaan yang bergerak di bidang produksi minuman susu fermentasi susu bubuk skim yang mengandung bakteri asam laktat hidup lactobacillus casei shirota strain pada tahun 1930, Dr.minoru shirota pendiri perusahaan yakult telah berhasil mengkulturkan berbagai jenis bakteri asam laktat dan memilih satu jenis bakteri yang bersifat paling tahan terhadap cairan pencernaan di samping itu Dr. minoru shirota juga memperkuatnya sehingga menjadi strain baru yang unggul karena itu berbeda dengan bakteri lain. Bakteri ini dapat menaklukan berbagai hambatan fosiologi asam lambung dan cairan empedu. Pada sejarahnya yakult di produksi dan di pasarkan diluar jepang yaitu taiwan pada tahun 1964, kemudian di ikuti dengan hal yang sama di negara negara Asia,Australia,dan Eropa. Sampai saat ini jaringan global berkembang meliputi 27 negara dan di konsumsi sebanyak 25 juta botol setiap hari melalui penggalian terhadap ilmu pengetahuan yakult terus berusaha menemukan cara baru untuk membuat kita lebih sangat berkualitas. (Andika Surya)

Setiap produk pasti memiliki kelebihan dan kekurangan, ketika konsumen mengkonsumsi minuman yakult maka kesehatan tubuh konsumen bisa terjaga, bisa membangun imunitas tubuh, mengatasi infeksi lambung dan memperlancar pencernaan. Tetapi kekurangan beberapa konsumen pada umumnya merasakan efek samping yakult. konsumen merasakan efek samping yaitu tidak nyaman pada bagian pencernaan karna minuman yakut memiliki rasa sedikit kecut terus konsumen merasa sakit kepala di karenakan yakult kaya akan probiotik, probiotik jika di komsumsi secara berlebihan maka konsumen akan merasa sakit kepala dan juga yakult mengandung amina biogenik. Biogenik itu sendiri zat yang terbentuk ketika makanan yang mengandung protein di fermentasi oleh bakteri, dan selanjutnya konsumen memiliki peluang terjadi alergi karna memang konsumen tertentu ternyata memiliki alergi pada salah satu atau beberapa jenis bahan yang menjadi komposisi yakult maka disini di sarankan untuk memebaca komposisi yang tertera di lebel yakult. Dari sinilah apakah sikap konsumen akan menyukai dan konsumen merasa puas terhadap pruduk yakult karna sikap terhadap merek sering mempengaruhi konsumen untuk membeli atau tidak. Sikap positif terhadap merek akan memungkinkan konsumen membeli produk sebaliknya sikap negatif akan menghalangi konsumen membeli produk tertentu. Adapun tujuan masalah dalam penelitian ini yaitu untuk mengetahui sikap dan kepuasan konsumen terhadap minuman probiotik yakult.

\section{a. Sikap}

\section{Pengertian sikap}

Menurut Damiati (2017:36), sikap merupakan ekspresi dari kesukaan atau ketidaksukaan seseorang terhadap sesuatu, dan sikap terhadap merek tertentu seringkali mempengaruhi apakah konsumen akan membeli. Sikap positif terhadap merek tertentu akan memungkinkan konsumen untuk membeli merek tersebut. Sebaliknya, sikap negatif akan menghalangi konsumen untuk melakukan pembelian. 
Berdasarkan definisi tersebut dapat disimpulkan bahwa sikap konsumen adalah bagaimana perasaan konsumen terhadap suatu barang, suka atau tidak suka, sikap juga dapat menggambarkan kepercayaan konsumen terhadap berbagai atribut dan manfaat dari barang tersebut.

\section{Indikator sikap}

Indikator sikap menurut Fredereka dan chary (2010:79) yaitu :

a.) produk yang di beli adalah produk yang terbaik

b.) produk yang dibeli merupakan produk yang terkenal

c.) produk yang dibeli adalah produk yang di inginkan

d.) produk yang di beli adalah produk yang di sukai

e.) produk yang di beli adalah yang handal

\section{b. Kepuasan konsumen}

\section{Pengertian kepuasan konsumen}

Konsumen mengalami kepuasan yaitu jika kinerja lebih rendah dari yang diharapkan maka konsumen akan kecewa, tetapi kinerja yang memenuhi harapan pelanggan akan puas, jika kinerja dapat melebihi harapan pelanggan maka mereka akan merasa sangat puas atau senang ( Kotler 2012:25). Menurut Philip Kotler dan Kevin Ranne Keller (2014:177). Dikutip dari teori manajemen pemasaran, kepuasan konsumen adalah perasaan senang atau kecewa yang dihasilkan seseorang setelah membandingkan kinerja hasil yang diharapkan dengan kinerja yang diharapkan.

Memuaskan kebutuhan konsumen adalah keinginan setiap perusahaan. Selain faktor penting bagi kelangsungan hidup perusahaan, memuaskan kebutuhan konsumen dapat meningkatkan keunggulan persainagan. Konsumen yang puas akan produk dan pelayanan cenderung akan membeli kembali produk dan mengunakan kembali produk pada saat kebutuhan yang sama muncul kembali di kemudian hari. Dari hal ini kepuasan itu merupakan faktor kunci bagi konsumen dalam melakukan pembelian ulang yang merupakan porsi terbesar dari volumen penjualan perusahaan. Juga pada dasarnya tujuan dari bisnis yaitu bagaimana menciptakan konsumen merasa puas terhadap produk setiap Perusahaan harus bekerja sama dengan pelanggan internal dan eksternal untuk memenuhi kebutuhan mereka, dan bekerja sama dengan pemasok internal dan eksternal untuk menciptakan kepuasan pelanggan.

Kepusan konsumen adalah respon atau reaksi terhadap ketidak sesuaian antara tingkat kepentingan sebelumnya dan kinerja aktual yang disahkan setelah pengunaan atau pemakaian (Rangkuti 2013:31).Tingkat kepuasan merupakan fungsi dari perbedaan antara kinerja yang di rasakan dengan harapan. Apabila kinerja di bawa harapan maka konsumen akan sangat kecewa sebaliknya bila kinerja sesuai harapan maka konsumen akan sangat puas sedangkan kinerja melebihi harapan konsumen sangat puas harapan kosumen dapat di bentuk oleh pengalaman masa lalu komentar dan keberatan serta janji dan informasi dari berbagai media. Konsumen yang puas akan setia lebih lama dan kurang sensitif dengan harga dan juga memberikan komentar yang baik tentang perusahaan.

\section{Indikator kepuasan konsumen}

Hawkins dan Lonney di kutip dalam Tjiptono(2014:147) indikator pembetukan kepuasan konsumen terdiri dari :

a.) Kesesuaian harapan Merupakan tingkat antara kesesuain harapan dan kinerja produk maupun jasa yang di harapkan oleh konsumen dengan yang di harapkan konsumen.

b.) Minat membeli kembali produk Merupakan kesediaan konsumen untuk membeli kembali atau melakukan pemakaian ulang terhadap produk terkait

c.) Kesedian merekomendasi Merupakan kesediaan konsumen untuk merekomendasikan produk yang telah di rasakan kepada teman atau keluarga 


\section{c. Hipotesis}

Hipotesis adalah jawaban sementara terhadap rumusan masalah penelitian di mana rumusan masalah telah di nyatakan dalam kalimat pertanyaan (sugiyono 2011:64). Berdasarkan teori teori yang di paparkan di atas dapat di ajukan hipotesis sebagai berikut

1. Hipotesis Penelitian

di duga sikap konsumen terhadap minuman probiotik yakult studi kasus masyarakat kota Bima di atas kriteria yang telah di tetapkan $70 \%$ di terima.

2. Hipotesis Statistik

$H_{0}: \geq 70 \%$ : di duga sikap konsumen minuman probiotik yakult studi kasus masyarakat kota Bima di bawah kriteria yang telah di tetapkan $70 \%$ di tolak

$H_{a}:<70 \%$ : di duga sikap konsumen minuman probiotik yakult studi kasus masyarakat kota Bima di atas kriteria yang telah di tetapkan

3. Hipotesis Penelitian $70 \%$ di terima.

di duga sikap konsumen terhadap minuman probiotik yakult studi kasus masyarakat kota Bima di atas kriteria yang telah di tetapkan $70 \%$ di terima.

4. Hipotesis Statistik

$H_{0}: \geq 70 \%$ : di duga kepusan konsumen minuman probiotik yakult studi kasus masyarakat kota Bima di bawah kriteria yang telah di tetapkan $70 \%$ di tolak

$H_{a}:<70 \%$ : di duga kepuasan konsumen minuman probiotik yakult studi kasus masyarakat kota Bima di atas kriteria yang telah di tetapkan $70 \%$ di terima.

\section{METODE PENELITIAN}

Dalam penelitian digunakan Jenis penelitian deskriptif. Penelitian deskrptif yaitu suatu metode dalam menelitian yang di lakukan untuk mengetahui nilai mandiri baik satu variabel atau lebih (independen) tampa membuat perbandingan (sugiyono,2012:55). Adapun instrumen penelitian di gunakan dalam pengumpulan data adalah dengan mengunakan skala liker. Populasi dalam kegiatan ini masyarakat kota bima yang pernah minum minuman probiotik yakult yang jumlahnya tidak di ketahui (unknown population) Populasi adalah wilyah generalisasi yang terdiri atas obyek/subyek yang mempunyai kualitas dan karakteristik tertentu di tetapkan oleh peneliti untuk di pelajari dan di tarik kesimpulan (sugiyono(2012:115). Sampel Sugiyono (2014:81) Mengungkapkan bahwa sampel adalah bagian dari jumlah dan karakteristik yang dimiliki oleh populasi tersebut. Dikarenakan jumlah populasi dalam penelitian ini tidak di ketahui secara pasti maka untuk mengetahui besarnya sampel yaitu menggunakan rumus cochran dan dan diperoleh sampel sebanyak 96 orang Ridwan (2015:65). Tehnik sampling adalah tehnik pengambilan sampel untuk menentukan sampel yang akan di gunakan dalam penelitian (sugiyono 2013:118). Ternik sampling dalam penelitian ini adalah purposive sampling, Menurut notoatmojo (2010) porposive sampling adalah pengambilan sampel yang berdasarkan atas suatu pertimbangan seperti sifat sifat atau ciri ciri yang sudah di ketahui sebelumnya. Tehnik pengumpulan data yang di gunakan yaitu Studi pustaka, obserevasi dan angket. Tehnik analisis data yang di gunakan dalam penelitian ini yaitu uji validitas, uji realibilitas dan one sampel t-test dan Adapun lokasi ataupun tempat penlitian yaitu di Kota Bima Nusa Tenggara Bara

\section{HASIL DAN PEMBAHASAN}

\section{Uji Validitas}

Dari hasil pengujian validitas terhadap setiap pernyataan instrumen penelitian pada variabel sikap konsumen dan kepuasan konsumen dapat dikatakan semua item 
pernyataan yang diajukan dalam penelitian ini adalah valid karena berada diatas standar validitas yaitu $>0,300$

\section{Uji Reliabilitas}

Tabel . 1

Reliability Statistics

variabel sikap

\begin{tabular}{|l|l|}
\hline $\begin{array}{l}\text { Cronbach's } \\
\text { Alpha }\end{array}$ & N of Items \\
\hline .917 & 10 \\
\hline
\end{tabular}
Sumber: Output SPSS Versi 23

Berdasarkan Tabel 1 diatas, diperoleh nilai Cronbach's Alpha sebesar 0,917 lebih besar dari 0,6 sehingga dapat ditarik kesimpulan bahwa variabel sikap konsumen sudah reliable.

Tabel .2

Reliability Statistics

variabel kepuasan

konsumen

\begin{tabular}{l|l|}
\begin{tabular}{|l|l|}
\hline $\begin{array}{l}\text { Cronbach's } \\
\text { Alpha }\end{array}$ & N of Items \\
\hline .902 & 9 \\
\hline
\end{tabular} \\
Sumber: Output SPSS Versi 23
\end{tabular}

Berdasarkan Tabel 2 diatas, diperoleh nilai Cronbach's Alpha sebesar 0,902 lebih besar dari 0,6 sehingga dapat ditarik kesimpulan bahwa variabel kepuasan konsumen sudah reliable.

\section{One Sample T-Test}

Tabel . 3 One Sample Statistic X1 (Sikap Konsumen) One-Sample Statistics

\begin{tabular}{|l|l|l|l|l|}
\hline & $\mathrm{N}$ & Mean & $\begin{array}{l}\text { Std. } \\
\text { Deviation }\end{array}$ & $\begin{array}{l}\text { Std. Error } \\
\text { Mean }\end{array}$ \\
\hline $\begin{array}{l}\text { SIKAP } \\
\text { KONSUMEN }\end{array}$ & 96 & 39.65 & 5.311 & .542 \\
\hline
\end{tabular}

Sumber: Output SPSS Versi 23

Kemudian semua nilai tersebut di subtitusikan ke rumus t-test satu sampel dengan mengunakan spss 23. 
Tebel .4 One Sample T-Test X1 (Sikap Konsumen) One-Sample Test

\begin{tabular}{|c|c|c|c|c|c|c|}
\hline & \multicolumn{6}{|c|}{ Test Value $=70$} \\
\hline & \multirow[b]{2}{*}{$\mathrm{T}$} & \multirow[b]{2}{*}{ Df } & \multirow{2}{*}{$\begin{array}{l}\text { Sig. } \\
\text { tailed })\end{array}$} & \multirow{2}{*}{$\begin{array}{l}\text { Mean } \\
\text { Difference }\end{array}$} & \multicolumn{2}{|c|}{$\begin{array}{l}95 \% \text { Confidence Interval } \\
\text { of the Difference }\end{array}$} \\
\hline & & & & & Lower & Upper \\
\hline $\begin{array}{l}\text { SIKAP } \\
\text { KONSUMEN }\end{array}$ & -65.219 & 95 & .000 & -35.354 & -36.43 & -34.28 \\
\hline
\end{tabular}

Sumber: Output SPSS Versi 23

Berdasarkan tabel di atas diketahui $\mathrm{n} 1=96$ sehingga digunakan rumus t-test satu sampel. Nilai $t_{\text {tabel }}$ dapat dihitung dengan menggunakan $\mathrm{dk}=\mathrm{n}-1 \quad(96-1=95)$ dengan derajat kesalahan $5 \%,(0,05)$ maka diperoleh nilai $t_{\text {tabel }}=1,665$, karena nilai $t_{\text {hitung }}$ lebih besar dari $t_{\text {tabel }}(65,219>1,665)$ maka jatuh pada daerah penerimaan Ha artinya Ha terima dan Ho ditolak.

Hal tersebut menjawab dan membuktikan Ha yang menyatakan bahwa diduga sikap konsumen terhadap minuman probiotik Yakult diatas kriteria yang telah ditetapkan $70 \%$ diterima, ini sejalan dengan penelitian terdahulu Listia Devy, Sudiyarto, Indra Tjaha Amir 2019 yang juga menyatakan $\mathrm{Ha}$ di duga sikap konsumen di atas kriteria yang telah di tetapkan $70 \%$.

Tabel .5 One Sample Statistic X2 (Kepuasan Konsumen) One-Sample Statistics

\begin{tabular}{|l|l|l|l|l|}
\hline & $\mathrm{N}$ & Mean & $\begin{array}{l}\text { Std. } \\
\text { Deviation }\end{array}$ & $\begin{array}{l}\text { Std. Error } \\
\text { Mean }\end{array}$ \\
\hline $\begin{array}{l}\text { KEPUASAN } \\
\text { KONSUMEN }\end{array}$ & 96 & 36.25 & 4.999 & .510 \\
\hline
\end{tabular}

Kemudian semua nilai tersebut di subtitusikan ke rumus t-test satu sampel dengan mengunakan spss 23.

Tabel .6 One Sample T-Test X2 (Kepuasan Konsumen) One-Sample Test

\begin{tabular}{|c|c|c|c|c|c|c|}
\hline & \multicolumn{6}{|c|}{ Test Value $=70$} \\
\hline & \multirow[b]{2}{*}{$\mathrm{T}$} & \multirow[b]{2}{*}{ Df } & \multirow{2}{*}{$\begin{array}{l}\text { Sig. } \\
\text { tailed) }\end{array}$} & \multirow{2}{*}{$\begin{array}{l}\text { Mean } \\
\text { Difference }\end{array}$} & \begin{tabular}{|l|}
$95 \%$ \\
Interval \\
Difference
\end{tabular} & $\begin{array}{l}\text { Confidence } \\
\text { of the }\end{array}$ \\
\hline & & & & & Lower & Upper \\
\hline $\begin{array}{l}\text { KEPUASAN } \\
\text { KONSUMEN }\end{array}$ & -75.950 & 95 & .000 & -38.750 & $\mid-39.76$ & -37.74 \\
\hline
\end{tabular}

Sumber: Output SPSS Versi 23

Berdasarkan tabel di atas diketahui $\mathrm{n} 1=96$ sehingga digunakan rumus t-test satu sampel. Nilai $t_{\text {tabel }}$ dapat dihitung dengan menggunakan $d k=n-1 \quad(96-1=95)$ dengan derajat kesalahan $5 \%(0,05)$ maka diperoleh nilai $t_{\text {tabel }}=1,665$, karena nilai thitung lebih 
besar dari tabel $(75,950>1,665)$ maka jatuh pada daerah penerimaan $\mathrm{Ha}$ artinya $\mathrm{Ha}$ terima dan Ho ditolak.

Hal tersebut menjawab dan membuktikan Ha yang menyatakan bahwa diduga kepuasan konsumen terhadap minuman probiotik Yakult diatas kriteria yang telah ditetapkan $70 \%$ diterima, ini sejalan dengan penelitian terdahulu Listia Devy, Sudiyarto, Indra Tjaha Amir 2019 yang juga menyatakan Ha di duga sikap konsumen di atas kriteria yang telah di tetapkan $70 \%$.

\section{KESIMPULAN DAN SARAN}

\section{a. Kesimpulan}

Dari hasi penelitian dapat di simpulkan bahwa sikap konsumen terhadap minuman probiotik yakult di atas kriteria yang telah di tetapkan $70 \%$ di terima dan juga kepusan konsumen terhadap minuman probiotik yakult di atas kriteria yang telah di

b. Saran tetapkan $70 \%$ di terima pula.

Saran untuk perusahaan yaitu Perusahaan harus mampu berinovasi agar konsumen merasakan kepuasan kepuasan konsumen akan berdampak pada sikap konsumen terhadap produk. Bagi penilitian selanjunya agar bisa menabah variabel terbaru agar penelitian bisa lebih baik dari penelitian terdahulu dan mencari objek penelitian yang lain.

\section{DAFTAR PUSTAKA}

Damiati ,dkk ISBN 978-602-425-199-4. Hal 36 ,thn 2017

Fredereca dan Chary.2010. pengaruh psikologi konsumen tehadap keputusan kembali smartphone blacberry.jurnal manajemen teory dan terapan. Vol 3. No 2, hal 128-143 di akses 3 maret 2013

Hizkia Elfran Mawey. Motivasi dan sikap konsumen pengaruhnya terhadap keputusan pembelian produk PT. Rajawali Nusindo Cabang Manado.jurnal EMBA Vol. 1 No. 4 aDesember 2013.Hal 191-801

Kotler, Philip dan Gerry Amstrong ,(2014): Principle of Marketing, 15th edition. New Jersey: pearson pretice Hall

Kotler ,Philip. 2012. Dasar dasar Nanajemen.BPEE. yogyakarta

Listia Devy, Sudiyarto, Indra Tjaha Amir 2019: Analisis sikap dan kepusan konsumen: Berkala ilmiah Agribisnis AGREDIVINA :Vol 8. No 1 juli 2019

Notoadmojo, Soekidjo,2012 pendidikan dan prilaku kesehatan . Jakarta:Rineka Cipta

Prof. Dr. Sugiyono. 2018. Metode penelitian kuantitatif, kualitatif, dan R\&D. Alfabeta. S, Lia Angriani dan kirana

Rangkuti, F. 2011. Riset pemasaran. Gramedia Pustaka Umum, Jakarta. R. Gulla, S. G . Oroh,. F.Roring. Jurnal EMBA. VOL 3. NO 1. Maret 2015,. Hal. 1313-1322

Sangadji, E.M., Dan Sophia 2013. Perilaku konsumen: pendekatan praktisi di sertai himpunan jurnal peneilitian.yogyakarta penebit andi. 
Sangadji, E.M., Dan Sophia 2013. sikap dan presepsi konsumen terhadapat kepuutusan pembelian online di sungai Lilin Musi bayuansin juriah,GenotAgung Busono, Deni Fadeli Jurnal manajemen vol. 6. No 2 juni 2017

Sartika moha, Sjendry londong. Jurnal EMBA,Vol.4 NO.1. MARET 2016 Hal 575-584

Surya Andik, 2019. profil perusahaan yakult. https://id.scribd.com/doc/310812240/ProfilPerusahaan-Yakult 